\title{
Fresh Bitter Melon Fruit (Momordica charantia) Attenuated Oxidative Stress, Fibrosis and Renal Injury in Carbon Tetrachloride Treated Rats
}

\author{
Md Abu Taher Sagor, Hasan Mahmud Reza, Nabila Tabassum, \\ Md. Moshfequr Rahman and Md. Ashraful Alam
}

\author{
Department of Pharmaceutical Sciences, School of Health and Life Sciences, North South University \\ Bashundhara, Dhaka-1229, Bangladesh
}

(Received: October 04, 2017; Accepted: November 10, 2017; Published (web): December 23, 2017)

\begin{abstract}
Chemical or drug-induced kidney damage is increasing every year and the end-stage renal disease is becoming a burden for health care system of many countries. Oxidative stress may be a crucial pathway for the development of end-stage renal disease. Thus, natural antioxidant or plant-based therapy would be a better alternative to protect renal function against chemical-induced renal damage. To determine these aspects we evaluated renoprotective effects of $M$. charantia in carbon tetrachloride administered rats. A $10 \% \mathrm{w} / \mathrm{w}$ mixture of fresh fruits of $M$. charantia was given with the chow food every day to $\mathrm{CCl}_{4}$ treated rats. After fourteen days, all animals were sacrificed and the kidneys were examined to observe the possible protective effects of $M$. charantia against $\mathrm{CCl}_{4}$ induced toxicity. The $\mathrm{CCl}_{4}$ treated rats showed increased oxidative stress parameters and decreased antioxidant enzymes activities. Supplementation of $10 \% \mathrm{w} / \mathrm{w}$ M. charantia fruits in $\mathrm{CCl}_{4}$ administered rats prevented the oxidative stress and restored the antioxidant enzymes activities. $M$. charantia fruits supplementation also prevented the rise of uric acid and creatinine concentration in plasma of $\mathrm{CCl}_{4}$ treated rats. Furthermore, histological studies showed that supplementation of $10 \% \mathrm{w} / \mathrm{w}$ M. charantia fruits prevented the collagen deposition, immune cell migration and iron deposition in kidney sections of $\mathrm{CCl}_{4}$ treated rats. The results of this study revealed that the fruits of $M$. charantia may protect oxidative stress-mediated damage in kidneys due to $\mathrm{CCl}_{4}$ administration, which is mediated probably via the restoration of anti-oxidant enzyme functions.
\end{abstract}

Key words: Renal dysfunction, carbon tetrachloride, malondialdehyde, superoxide dismutase, Oxidative stress, Momordica charantia.

\section{INTRODUCTION}

Diabetes, obesity, insulin resistance and hypertension have been increasing very fast and these are becoming an epidemic which leads to kidney dysfunctions like nephritis, hypertrophy proteinuria and podocyte injury as well as apoptosis. ${ }^{1}$ These factors increase mortality rate and put the extra burden on the patient and thereby increasing the overall cost of the treatment. ${ }^{2}$ Carbon tetrachloride $\left(\mathrm{CCl}_{4}\right)$, a synthetic halogenated and the highly lipid soluble molecule, is applied on various laboratory animal models to study the potential roles of an

Correspondence to: Md. Ashraful Alam

Email: sonaliagun@yahoo.com and

Dr Hasan Mahmud Reza

Email: hasan.reza@northsouth.edu

Dhaka Univ. J. Pharm. Sci. 16(2): 205-214, 2017 (December) active molecule, plant or and microbe. ${ }^{3} \mathrm{CCl}_{4}$ is not only known as a hepatotoxin ${ }^{4}$ but it also significantly affects the heart, ${ }^{5}$ brain, ${ }^{6}$ lung, ${ }^{7}$ reproductive organs and most importantly in kidney. ${ }^{8}$ The actual mechanism of $\mathrm{CCl}_{4}$ in the kidney is yet not clear but it is described that the pathogenic pathway is depending onto free radical-mediated oxidative stress. ${ }^{9}$ However, the study described that $\mathrm{CCl}_{4}$ undergoes biotransformation through CYP- $2 \mathrm{E}_{1}$ and converts to a highly reactive molecule named trichloro-chloride radical $\left({ }^{\circ} \mathrm{OOCCl}{ }_{3}\right)^{10}$ which further produces lipid peroxidation by oxidizing membrane lipid resulting cellular damage. ${ }^{11} \mathrm{~A}$ recent study focused that metabolites of $\mathrm{CCl}_{4}$ lowered the amount of natural anti-oxidation capacity i.e-SOD, GSH, 
GPX, catalase, ascorbate and hemeoxygenase. ${ }^{12}$ Our previous study revealed that free radicals generated from $\mathrm{CCl}_{4}$ invites various immune cells like macrophages, monocytes, mast cell, T-cells and neutrophil which further recruit various proinflammatory cytokines such as tumor necrosis factor- $\alpha$, interleukins- $1 \beta$, nuclear factor- $\beta$, macrophage inflammatory protein and many more. Furthermore, oxidative stress induces pro-fibrogenic molecules like matrix metalloproteinase, transforming growth factor- $\beta$ and $\mathrm{F}_{2 \mathrm{t}}$-Isoprostane to activate local fibroblastic tissue which secret extra cellular matrix and collagen around the injured tissue. Taken together, free radicals often disturb heme oxygenase which regulates iron metabolism. ${ }^{13}$

Modern medicines focus not only towards active drug constituents but also traditional medicines including various plants, herbs, animals, microorganisms and marine creatures in disease prevention. ${ }^{14}$ The study also suggested that traditional medicines which contain anti-oxidant property can reduce free radical generation. ${ }^{15} M$. charantia is a well-investigated plant which was used as antimalarial, analgesic and anti-inflammatory, antiobesity, anti-hyperlipidemic and anti-diabetic agents. This plant possesses several groups of bioactive molecules like polyphenols, flavonoids, glycosides, triterpenes, tannins and fixed oils. ${ }^{16}$ Our previous study found out that $10 \% \mathrm{w} / \mathrm{w}$ fruit supplementation of $M$. charantia with food ameliorated hepatic damage, oxidative stress and fibrosis. ${ }^{17}$ Interestingly, the renoprotective activity of this plant has not been focused well on $\mathrm{CCl}_{4}$ induced animal model. Therefore, this study will reveal renoprotective activities of $M$. charantia by reducing oxidative stress-mediated kidney damage, inflammation and fibrosis.

\section{MATERIALS AND METHODS}

Chemicals and reagents. Thiobarbituric acid (TBA) was purchased from Sigma Chemical Company (USA). Reduced glutathione (GSH) and trichloroacetic acid (TCA) were purchased from J.I. Baker (USA). Uric acid (UA), creatinine assay kits were obtained from DCI diagnostics (Budapest, Hungary), 50, 50-dithiobis-2-nitrobenzoate (Ellman's reagent) from Sigma (USA) and sodium hydroxide from Merck (Germany). All other chemicals and reagents used were of analytical grade.

Animals used and experimental protocol. Eight to ten weeks old, 28 Long Evans female rats (160-170 gram each) were obtained from Animal Production Unit of Animal House at Department of Pharmaceutical Sciences, North South University and were kept in individual cages in an air-conditioned room where the temperature was maintained at $22 \pm$ $3^{\circ} \mathrm{C}$ with a 12 hours dark/light cycles. Rats had access to standard laboratory feed (Pellet foods) and mineral water, according to the study protocol which was approved by Ethical Committee of Department of Pharmaceutical Sciences, North South University for animal care and experimentation. To observe the reno-protective effects of $M$. charantia, rats were divided into four groups (6-8 rats in each group) named as Control (Group A), Control + M. charantia (Group B), $\mathrm{CCl}_{4}$ (Group C) and $\mathrm{CCl}_{4}+M$. charantia (Group D). Only rats of group B and D were provided M. charantia supplement. All animals were checked for body weight, food and water intake on a daily basis. After 14 days of grouping, all animals were weighed, sacrificed, and all internal organs such as heart, kidney and spleen were taken. Immediately after collection of the organs, they were weighted and stored in neutral buffered formalin $(\mathrm{pH}$ 7.4) to be processed for histology. Rat kidney tissue was homogenized and centrifuged in $8000 \mathrm{rpm}$ for 10 minutes then the clear solution was taken. Immediately after collecting solutions, tissue were stored in $-20^{\circ} \mathrm{C}$ for further biochemical analysis to observe the possible oxidative mediated renal dysfunctions.

Administration of $\mathrm{CCl}_{\mathbf{4}}$ and treatment with $\boldsymbol{M}$. charantia. Two types of bitter melon are available in the market. Smaller fruits were used in this study instead of larger. Fresh M. charantia was purchased from local market, then washed properly and dried at room temperature. Later, the fruits have compressed a mixture of a blender and $10 \%$ w/w given every day 
with the chow food. Momordica charantia has been identified by Mr. Sarker Nasir Uddin, Senior Scientific Officer, of National Herbarium, Mirpur, Dhaka Bangladesh and a receipt was deposited (Accn. No. 40566) for future reference.
Assessment of biochemical parameters. Kidney markers uric acids (UA) and creatinine were estimated in kidney tissue by using Diatec diagnostic kits (Hungary) according to the manufacturer's protocol.

Table 1. Different animal groups and their treatment strategies used in this study.

\begin{tabular}{|c|c|c|c|}
\hline Group A & Group B & Group C & Group D \\
\hline Number: 6 & Number: 6 & Number: 8 & Number: 8 \\
\hline Duration:14 days & Duration: 14 days & Duration: 14 days & Duration: 14 days \\
\hline $\begin{array}{l}\text { Treatment: given } \\
\text { only oral olive oil } 3 \\
\mathrm{ml} / \mathrm{kg} \mathrm{bw}\end{array}$ & $\begin{array}{l}\text { Treatment: } 10 \% \mathrm{w} / \mathrm{w} M . \\
\text { charantia with food alone with } \\
\text { oral olive oil } 3 \mathrm{ml} / \mathrm{kg} \text { bw }\end{array}$ & $\begin{array}{l}\text { Treatment: given oral olive oil } \\
3 \mathrm{ml} / \mathrm{kg} \text { bw }+\mathrm{CCl}_{4} 1 \mathrm{ml} / \mathrm{kg} \text { bw } \\
\text { twice a week }\end{array}$ & $\begin{array}{l}\text { Treatment: given oral olive oil } 3 \mathrm{ml} / \mathrm{kg} \\
\text { bw }+\mathrm{CCl}_{4} 1 \mathrm{ml} / \mathrm{kg} \text { bw twice a week with } \\
10 \% \text { w/w } M . \text { charantia }\end{array}$ \\
\hline
\end{tabular}

Determination of lipid peroxidation (LPO) as malondialdehyde (MDA). Lipid peroxidation in kidney was estimated calorimetrically measuring malondialdehyde followed by previously described protocol. ${ }^{18}$ Samples $(1 \mathrm{ml})$ were mixed with $1 \mathrm{ml}$ of $0.67 \%$ thiobarbituric acid and placed in a boiling water bath for $10 \mathrm{~min}$. The mixture was cooled and diluted with $1 \mathrm{ml}$ distilled water. The absorbance of the solution was then read using spectrophotometer at $532 \mathrm{~nm}$. The content of malondialdehyde (MDA) $(\mathrm{nmol} / \mathrm{ml})$ was then calculated, by reference to a standard curve of MDA solution.

Determination of nitric oxide (NO). Nitric oxide (NO) was determined according to the method described previously as nitrate. ${ }^{19}$ In the study, Griess-Illosvoy reagent was modified by using naphthyl ethylene diamine dihydrochloride $(0.1 \%$ w/v) instead of 1-naphthylamine (5\%). The reaction mixture $(3 \mathrm{ml})$ containing tissue sample $(2 \mathrm{ml})$ and phosphate buffer saline $(0.5 \mathrm{ml})$ was incubated at $25^{\circ} \mathrm{C}$ for $150 \mathrm{~min}$. A pink colored chromophore was formed in diffused light after addition of modified Griess-Illosvoy reagent. The absorbance of these solutions was measured at $540 \mathrm{~nm}$ against the corresponding blank solutions. NO level was measured by using the standard curve and expressed as $\mathrm{nmol} / \mathrm{mL}$.

Determination of advanced protein oxidation products (APOP) assay. Determination of APOP levels was performed by modification of the previously described method elsewhere. ${ }^{20,21}$ Two $\mathrm{mL}$ of tissue sample was diluted 1:5 in PBS: $0.1 \mathrm{ml}$ of $1.16 \mathrm{M}$ potassium iodide was then added to each tube, followed by $0.2 \mathrm{ml}$ acetic acid after $2 \mathrm{~min}$. The absorbance of the reaction mixture was immediately read at $340 \mathrm{~nm}$ against a blank containing $2 \mathrm{ml}$ of PBS, $0.1 \mathrm{ml}$ of KI, and $0.2 \mathrm{ml}$ of acetic acid. The chloramine-T absorbance at $340 \mathrm{~nm}$ was found linear within the range of 0 to $100 \mathrm{nmol} / \mathrm{ml}$, APOP concentrations were expressed as $\mathrm{nmol} / \mathrm{ml}$ chloramine-T equivalents.

Determination of catalase (CAT) activity. CAT activities were determined using previously described method elsewhere. ${ }^{22,23}$ The reaction solution of CAT activities contained $2.5 \mathrm{ml}$ of 50 mmol phosphate buffer ( $\mathrm{pH} 5.0$ ), $0.4 \mathrm{ml}$ of $5.9 \mathrm{mmol}$ $\mathrm{H}_{2} \mathrm{O}_{2}$ and $0.1 \mathrm{ml}$ enzyme extract. Changes in absorbance of the reaction solution at $240 \mathrm{~nm}$ were determined after one minute. One unit of CAT activity was defined as an absorbance change of 0.01 as units/min.

Determination of reduced glutathione assay (GSH). Reduced glutathione was estimated by previously described method. ${ }^{24}$ One (1.0) $\mathrm{ml}$ of $10 \%$ tissue sample was precipitated with $1.0 \mathrm{ml}$ of $(4 \%)$ sulfosalicylic acid. The samples were kept at $4^{\circ} \mathrm{C}$ for $1 \mathrm{hr}$ and then centrifuged at $1200 \times \mathrm{g}$ for $20 \mathrm{~min}$ at $4^{\circ} \mathrm{C}$. The total volume of $3.0 \mathrm{ml}$ assay mixture composed of $0.1 \mathrm{ml}$ filtered aliquot, $2.7 \mathrm{ml}$ phosphate buffer (0.1 M, pH 7.4) and $0.2 \mathrm{ml}$ DTNB (5,5- 
dithiobis-2-nitrobenzoic acid), (100 mM). The absorbance of the yellow color mixture was read immediately at $412 \mathrm{~nm}$ on a Smart Spec TM plus Spectrophotometer and expressed as $\mathrm{ng} / \mathrm{mg}$ protein.

Determination of superoxide dismutase (SOD). The determination of SOD was performed by a modified procedure previously described elsewhere. ${ }^{25}$ Briefly, each $300 \mu$ reaction mixture contained $50 \mathrm{mM}$ sodium phosphate $(\mathrm{pH} 7.8), 13$ $\mathrm{mM}$ methionine, $75 \mathrm{mM}$ nitrobluetetrazolium (NBT), $2 \mathrm{mM}$ riboflavin, $100 \mathrm{mM}$ EDTA, and $2 \mathrm{ml}$ of tissue sample. The change in absorbance of each sample was then recorded at $560 \mathrm{~nm}$ for the production of blue formazan. Results were expressed as percentage activity of SOD enzyme. The equation for measuring the activity of SOD was $=$ [(Initial absorption subsequent absorption at $30 \mathrm{~s}$ interval)/Initial absorption] x 100.

Estimation of total protein concentration. Total protein in tissue was determined by BCA protein acid kit (Thermo Scientific) according to the manufacturer's protocol.

\section{Histopathological}

determination of inflammation, fibrosis and iron overload. For microscopic evaluation, kidney tissue was fixed in neutral buffered formalin and embedded in histology graded paraffin, sectioned at $5 \mu \mathrm{m}$ with the help of Microtome and subsequently stained with hematoxylin and eosin to evaluate inflammatory cell migration. Sirius red staining was also performed to evaluate the fibrosis in kidney sections. Moreover, prussian blue staining was also performed to determine the iron overload in kidney tissues. The slides were basically examined for pathomorphological changes. Sections were studied under a light microscope at $40 \times$ magnifications.

Statistical analysis. The values are expressed as a mean \pm standard error of the mean (SEM). The findings were analyzed by using the one way ANOVA and with Bonferroni post hoc test using Graph Pad Prism software, version 6.0 (USA). Statistical significance was considered $p<0.05$ in all cases.

\section{RESULTS AND DISCUSSION}

Effect of $\mathrm{CCl}_{4}$ and $M$. charantia on body weight, food and water intake. Body weight of each rat was recorded every day during the experiment, and percentage change was calculated for all groups. It was found that the body weight increased consistently to only Group-A, on the other hand body weight of all groups was decreased gradually. Food and water intake was also found to decrease except for control group. Gradual weight loosing as well as losing food habit might be due to $\mathrm{CCl}_{4}$ intoxication and bitter test of fruits.

Effect of $\mathrm{CCl}_{4}$ and $M$. charantia on organ wet weight. Table 2 shows various effects of $\mathrm{CCl}_{4}$ and $M$. charantia on rat's organs wet weight. The wet weight of heart and kidney was decreased immediately after collection in $\mathrm{CCl}_{4}$ treated rats when compared with control rats. However, spleen wet weight was increased in $\mathrm{CCl}_{4}$ treated group as compared to control rats.

Effects on $\mathrm{CCl}_{4}$ and $M$. charantia on kidney markers. From our biochemical assay, it was found that tissue uric acid and creatinine concentration was quite high due to $\mathrm{CCl}_{4}$ administration and activation of free radicals pathogenic pathways. In all cases the kidney markers (uric acid and creatinine) values were found to be significant (Table 3).

Effects of $\mathrm{CCl}_{4}$ and $M$. charantia on natural anti-oxidant capacity system. Glutathione, which is considered as a potent anti-oxidant was found $(19.40 \pm 1.68 \mathrm{ng} / \mathrm{mg})$ in control kidney, while in $\mathrm{CCl}_{4}$ treated kidney it was almost half of the control group. Interestingly, treatment with $M$. charantia improved very well and the level was found more than the control group $(23.91 \pm 1.31)$. In case of SOD activity, $\mathrm{CCl}_{4}$ treated kidney $(13.57 \pm 1.70)$ lost less than half of control kidney $(29.19 \pm 1.64)$ and treatment (24.92 \pm 3.10) improved almost near to control group. Surprisingly, catalase was found much more in the treated group $(11.79 \pm 0.74)$ than the control rats $(9.03 \pm 0.83)$. In all cases, treatment with $M$. charantia was found to be safe when other groups were compared with Group B (Table 3). 
Table 2. Effect of $M$. charantia on various parameters in different groups of $\mathrm{CCl}_{4}$ treated rats.

\begin{tabular}{lcccc}
\hline Parameters & $\begin{array}{c}\text { Control } \\
\text { (Group A) }\end{array}$ & $\begin{array}{c}\text { Control }+ \text { M. charantia } \\
\text { (Group B) }\end{array}$ & $\begin{array}{c}\mathrm{CCl}_{4} \\
(\mathrm{Group} \text { C) }\end{array}$ & $\begin{array}{c}\mathrm{CCl}_{4}+\text { M. charantia } \\
\text { (Group D) }\end{array}$ \\
\hline Initial bw (g) & $164.23 \pm 2.66$ & $172.15 \pm 1.26$ & $168.76 \pm 2.36$ & $166.45 \pm 2.30$ \\
Final bw (g) & $177.82 \pm 3.27$ & $162.50 \pm 1.68$ & $162.71 \pm 3.01$ & $160.67 \pm 1.98$ \\
Food intake (g/day) & $19.16 \pm 2.10$ & $13.48 \pm 1.97$ & $12.92 \pm 1.40$ & $12.86 \pm 1.47$ \\
Water intake (ml/day) & $20.05 \pm 2.09$ & $19.18 \pm 1.82$ & $14.83 \pm 1.78$ & $14.98 \pm 2.34$ \\
$\begin{array}{l}\text { Both kidney wet weight } \\
\text { (g/100 g of bw) }\end{array}$ & $0.67 \pm 0.04$ & $0.63 \pm 0.02$ & $0.55 \pm 0.01$ & $0.60 \pm 0.01$ \\
Heart wet weight & $0.37 \pm 0.02$ & $0.35 \pm 0.01$ & $0.32 \pm 0.01$ & $0.34 \pm 0.01$ \\
(g/100 g of bw) & $0.28 \pm 0.02$ & $0.27 \pm 0.01$ & $0.26 \pm 0.01$ & $0.27 \pm 0.01$ \\
LV wet weight & & & \\
(g/100 g of bw) & $0.06 \pm 0.01$ & $0.05 \pm 0.01$ & $0.05 \pm 0.01$ & $0.05 \pm 0.01$ \\
RV wet weight & & & \\
(g/100 g of bw) & $0.38 \pm 0.02$ & $0.39 \pm 0.01$ & $0.43 \pm 0.03$ & $0.39 \pm 0.01$ \\
$\begin{array}{l}\text { Spleen wet weight } \\
\text { (g/100 g of bw) }\end{array}$ & & & \\
\hline
\end{tabular}

Values are presented as mean \pm SEM, where $n=6$. One way ANOVA with Bonferoni tests were done as post hoc test. Values are considered significance at $\mathrm{p}<0.05$.

Table 3. Effect of $M$. charantia on oxidative stress parameters in kidney of $\mathrm{CCl}_{4}$ treated rats.

\begin{tabular}{lcccc}
\hline Parameters & Control & $\begin{array}{c}\text { Control }+M . \\
\text { charantia }\end{array}$ & $\mathrm{CCl}_{4}$ & $\mathrm{CCl}_{4}+$ M. charantia \\
\hline Kidney & $13.09 \pm 0.71 \mathrm{a}$ & $10.46 \pm 0.83 \mathrm{a}$ & $20.96 \pm 1.28 \mathrm{~b}$ & $16.79 \pm 0.57 \mathrm{~b}, \mathrm{c}$ \\
Uric acid $(\mathrm{mg} / \mathrm{dL})$ & $15.76 \pm 0.84 \mathrm{a}$ & $14.82 \pm 1.27 \mathrm{a}$ & $26.57 \pm 1.38 \mathrm{~b}$ & $23.02 \pm 2.21 \mathrm{~b}$ \\
Creatinine $(\mathrm{mg} / \mathrm{dL})$ & $190.26 \pm 9.34 \mathrm{a}$ & $183.83 \pm 12.73 \mathrm{a}$ & $714.08 \pm 45.45 \mathrm{~b}$ & $534.77 \pm 43.30 \mathrm{~b}, \mathrm{c}$ \\
APOP $(\mathrm{nmol} / \mathrm{mL})$ & $56.49 \pm 1.82 \mathrm{a}$ & $50.52 \pm 2.87 \mathrm{a}$ & $86.87 \pm 3.55 \mathrm{~b}$ & $68.07 \pm 4.12 \mathrm{a}$ \\
MDA $(\mathrm{nmol} / \mathrm{mL})$ & $16.53 \pm 1.28 \mathrm{a}$ & $15.11 \pm 1.63 \mathrm{a}$ & $35.70 \pm 2.02 \mathrm{~b}$ & $29.30 \pm 0.93 \mathrm{~b}, \mathrm{c}$ \\
NO $(\mathrm{nmol} / \mathrm{mL})$ & $9.03 \pm 0.83 \mathrm{a}$ & $9.70 \pm 0.82 \mathrm{a}$ & $7.68 \pm 0.91 \mathrm{a}$ & $11.79 \pm 0.74 \mathrm{a}$ \\
Catalase $(\mathrm{U} / \mathrm{Min} / \mathrm{mg}$ protein) & $19.40 \pm 1.68 \mathrm{a}$ & $20.46 \pm 3.12 \mathrm{a}$ & $10.28 \pm 0.74 \mathrm{~b}$ & $23.91 \pm 1.31 \mathrm{a}$ \\
GSH $(\mathrm{ng} / \mathrm{mg}$ protein$)$ & $29.19 \pm 1.64 \mathrm{a}$ & $32.13 \pm 4.44 \mathrm{a}$ & $13.57 \pm 1.70 \mathrm{~b}$ & $24.92 \pm 3.10 \mathrm{a}$ \\
SOD $(\%$ of activity) & & & \\
\hline
\end{tabular}

Values are presented as mean \pm SEM. One way ANOVA with Bonferoni tests were done as post hoc test. Values are considered significance at $\mathrm{p}<0.05$. APOP-Advanced protein oxidation product, expressed as $\mathrm{nmol} / \mathrm{mL}$ equivalent to Chloramine-T. a $v s \mathrm{~b}$, control $v s$ $\mathrm{CCl}_{4} ; \mathrm{b}$ vs c, $\mathrm{CCl}_{4}$ vs treatment

Effects of $\mathrm{CCl}_{4}$ and $M$. charantia on oxidative stress markers. AOPP, NO and MDA are the 3 important markers which have been evaluated in the present study and found very high due to $\mathrm{CCl}_{4}$ administration. This indicates high oxidative stress inside disease group. Our biochemical assay found that control kidney contained (190.26 \pm 9.34) $\mathrm{nmol} / \mathrm{mL}$ AOPP, on the other hand $\mathrm{CCl}_{4}$ treated kidney showed almost three times $(714.08 \pm 45.45)$ $\mathrm{nmol} / \mathrm{mL}$ AOPP more than the control kidney. So the treated group significantly reduced AOPP level in the kidney. NO, which is a vasodilator as well as signaling molecules observed high $(35.70 \pm 2.02)$ in $\mathrm{CCl}_{4}$ group but $M$. charantia treatment lowered that concentration of nitric oxide $(29.30 \pm 0.93)$. We have also evaluated the MDA which is a product of damaged cell membrane. $\mathrm{CCl}_{4}$ treated rats produced an increased concentration of MDA $(86.87 \pm 3.55)$ as compared to the control rats $(56.49 \pm 1.82)$. However, treatment with bitter melon lowered this level (68.07 $\pm 4.12 \mathrm{nmol} / \mathrm{ml}$ ) (Table 3). 
Evaluation of fibrosis, inflammation and iron deposition in kidney. In each and every case of kidneys from $\mathrm{CCl}_{4}$ administrated rats (Figures 1C, 2C and $3 \mathrm{C}$ ), we found huge fibrosis, inflammatory cell accumulation and iron overload around the glomerulus which was not found in control group (Figures 1A, 2A and 3A). Although treatment with
$10 \%$ w/w M. charantia (Figures 1D, 2D and 3D) almost normalized collagen deposition, immune cell migration and iron accumulation when it was compared with control group. Treatment with $M$. charantia in control rats (Group B) did not show any pathological sign of liver damage as well as alteration in biochemical parameters (Figures 1B, 2B and 3B).
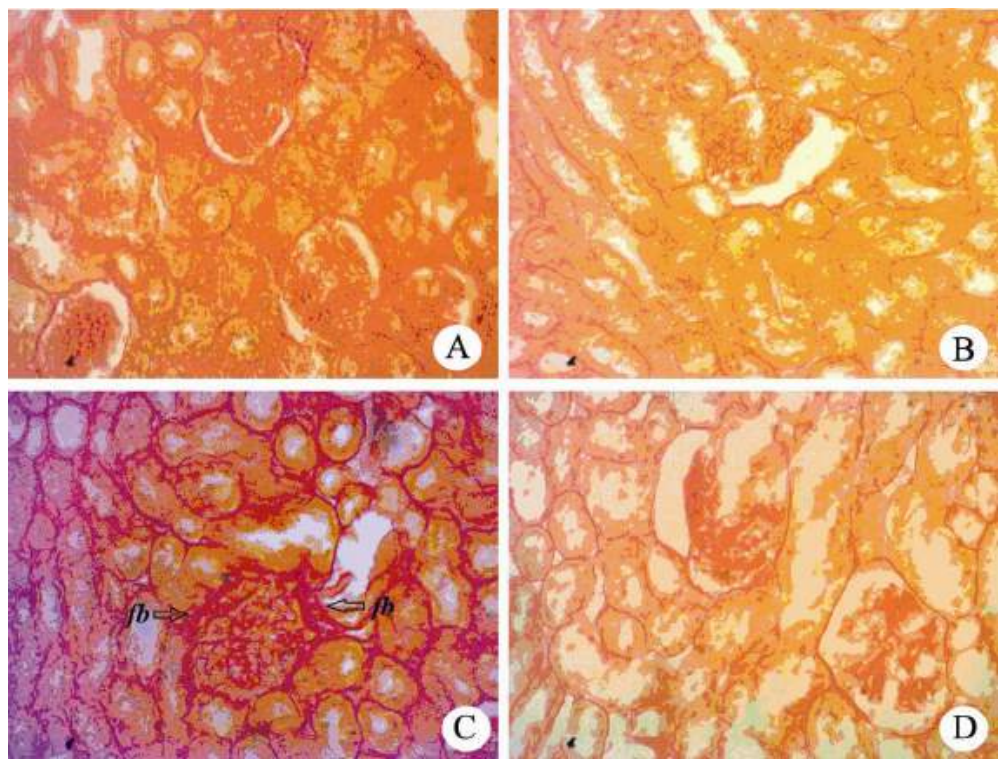

Figure 1. Sirius red staining showed fibrosis (Red color) in kidney section of various groups. A represents control kidney, B represents control $+M$. charantia kidney, $\mathrm{C}$ represents $\mathrm{CCl}_{4}$ treated kidney and $\mathrm{D}$ represents $\mathrm{CCl}_{4}+M$. charantia kidney. Magnification $40 \mathrm{X}$ was used. $f b$ - fibrosis.

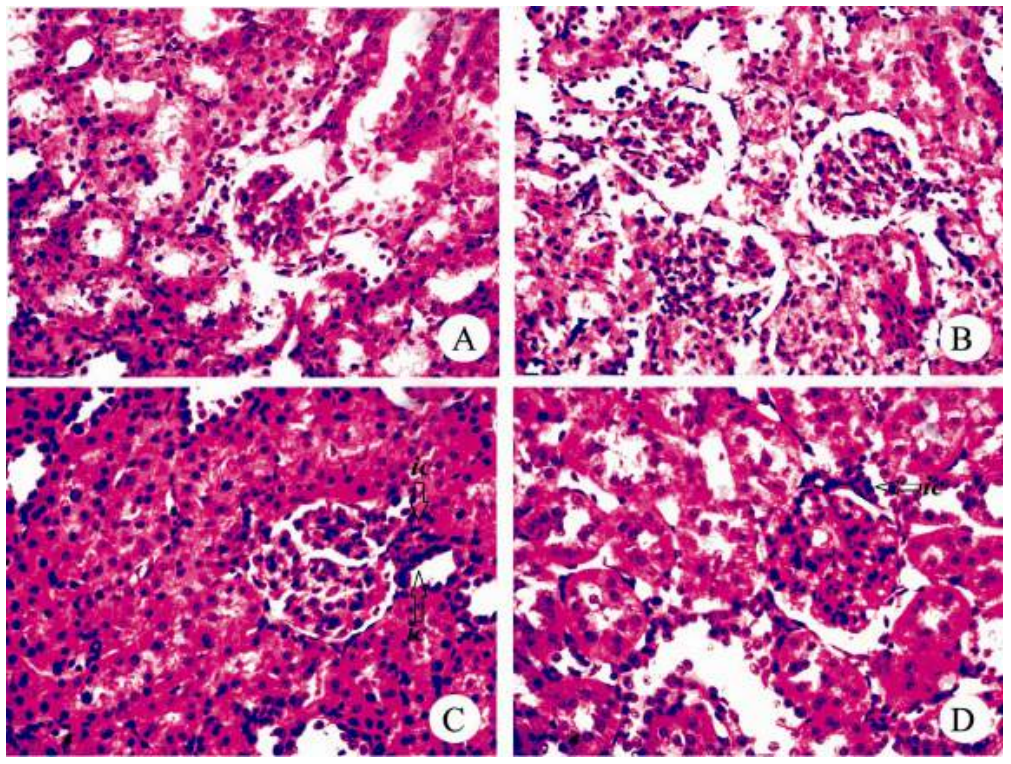

Figure 2. Hematoxylin and eosin staining showed inflammatory cell infiltration and necrosis in kidney of various groups. A represents control group, B represents control $+M$. charantia group, $\mathrm{C}$ represents $\mathrm{CCl}_{4}$ treated group and $\mathrm{D}$ represents $\mathrm{CCl}_{4}+M$. charantia group. Magnification $40 \mathrm{X}$ was used. ic- inflammatory cells. 


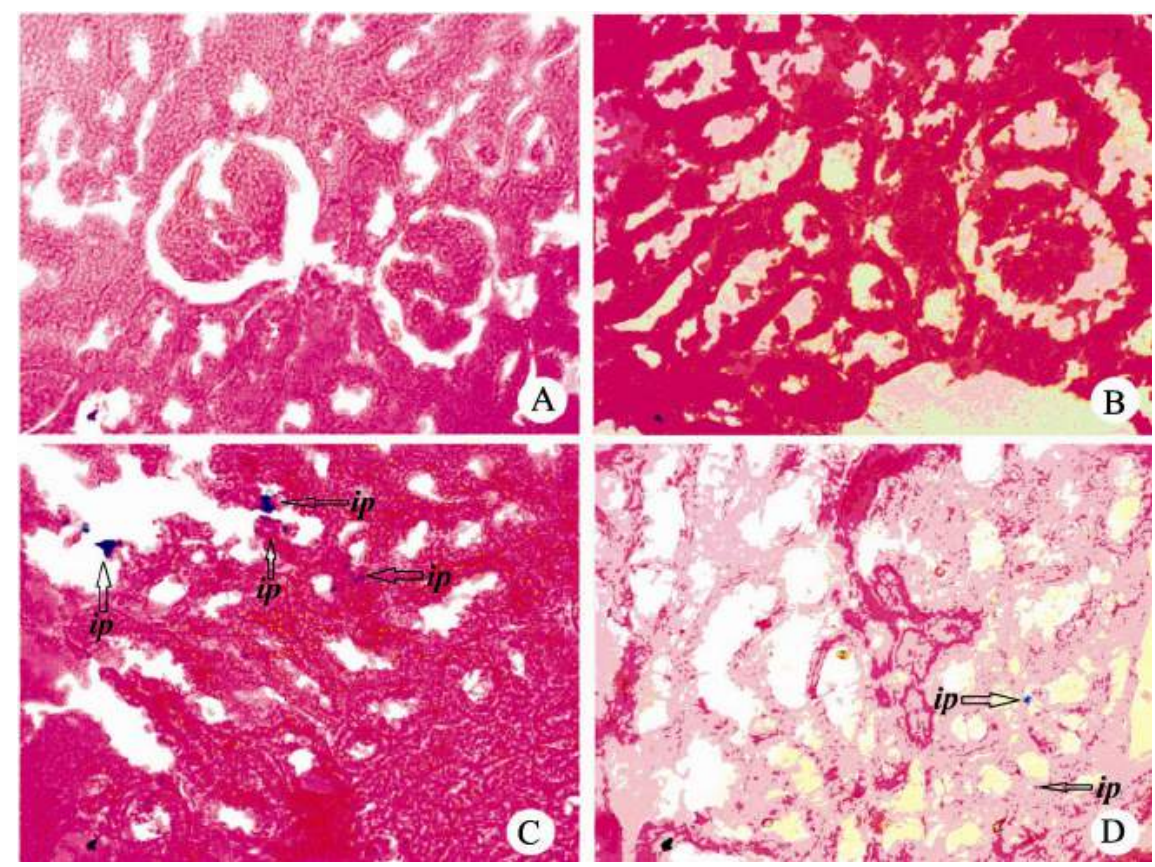

Figure 3. Prussian blue staining showed iron deposition in kidney section of various groups. A represents control group, B represents control + Momordica charantia group, $\mathrm{C}$ represents $\mathrm{CCl}_{4}$ treated group and $\mathrm{D}$ represents $\mathrm{CCl}_{4}+$ Momordica charantia group. Magnification 40X was used. ip- iron pigment.

The kidney plays several important roles to eliminate biological waste like dead cells, uric acid, unwanted muscle, several proteins via urine. It also produces several necessary hormones like vasopressin and erythropoietin, maintains $\mathrm{pH}$ of blood and other fluids, regulates blood pressure by renin and angiotensin system and most importantly it filters blood. ${ }^{26}$ Several diseases are initiated by uric acid which is the ultimate end product of purine metabolism. ${ }^{27}$ Unfortunately, uric acid acts as a potent oxidant and helps in the development of various pathogenesis such as hypertension and chronic kidney diseases to end-stage renal diseases. ${ }^{28}$ In the same way creatinine is the waste product of muscle catabolism which justifies that high level of creatinine either in plasma or kidney indicates kidney dysfunctions. ${ }^{29}$ Our study found that $\mathrm{CCl}_{4}$ treated rats produced higher uric acid and creatinine level in kidney, which were considered as the ultimate feature of kidney dysfunction and our treatment group significantly lowered creatinine as well as uric acid level. Similar kind of outcome has been observed in previous study in a renovascular hypertensive rat model. $^{30}$

Administration of $\mathrm{CCl}_{4}$ generates huge free radicals which further helps to produce malondialdehyde (MDA) that oxidize membrane lipid and damage kidney cell membrane. Later, immune cell is attracted around the damaging area to protect from the injury. ${ }^{31}$ Another group of authors has also observed that MDA level damages kidney cells and increases serum AST, ALP and ALT concentration. ${ }^{32}$ We have found enormous MDA level in $\mathrm{CCl}_{4}$ treated group which was normalized by bitter melon treatment through oral route. Nitric oxide, a signaling molecule that maintains vascular tone is generally induced by NOS but sometimes due to oxidative stress it may produce iNOS which is a dangerous molecule for damaging cell and recruit immune cell in an organ. ${ }^{33}$ Inside kidney, NO often reacts with highly reactive free radicals and produce more harmful compound like peroxynitrite. ${ }^{34} \mathrm{CCl}_{4}$ often travels to nucleus and interfere with genetic code like DNA, RNA, regulatory protein, genes and further produces faulty mRNA. Oxidizing genetic 
materials produce advanced oxidative protein products (AOPP) in the kidney. ${ }^{35}$ Our study found that treatment with only $\mathrm{CCl}_{4}$ produced high amount of NO and AOPP level and 10\% w/w bitter melon treatment significantly normalized concentration of both kidney tissue.

Carbon tetrachloride is well known toxicant which produces several oxidants and at the same time it reduces the amount of natural anti-oxidant defense capacity. $\mathrm{CCl}_{4}$ also generates hydrogen peroxide anion, superoxide anion $\left(\mathrm{O}_{2}{ }^{-}\right)$and hydroxyl radical ( $\mathrm{OH})$ etc. ${ }^{36}$ Furthermore, oxidative stress also helps in the production of $\mathrm{NAD}(\mathrm{P}) \mathrm{H}$ oxidase which is again responsible for mitochondrial damage in the kidney. ${ }^{37}$ SOD, GSH and catalase are known as natural anti-oxidants which are normally generated against any harmful stimuli. A previous previous study also described that kidney could be protected if the concentration of anti-oxidant is improved. ${ }^{38}$ Our study has observed that the level of anti-oxidants found lower on the $\mathrm{CCl}_{4}$ treated group and bitter melon treatment improved the level more than that of in the control group.

From the histological assessment, we observed that $\mathrm{CCl}_{4}$ treated rats showed massive immune cell infiltration, collagen deposition and iron pigment accumulation in the liver. On the other hand treatment with bittermelon significantly reduced inflammation, fibrosis and iron deposition in the liver of $\mathrm{CCl}_{4}$ administered rats. It is anticipated that the improvement of kidney histology as well as bio-assay proved that bitter melon treatment might be due to the significant anti-oxidant capacity. Our previous experiment also exposed that $M$. chrantia served as hepatoprotective by reducing oxidative stress as well as free radicals. ${ }^{17}$ The previous study also explored that bitter melon regulates peroxisome proliferatoractivated receptors (PPARs), monocyte chemoattractant protein-1 (MCP-1) and fatty acid synthesis (FAS) related genes. ${ }^{16}$ Bitter melon also reduced inflammatory, pro-inflammatory, fibrogenic, profibrogenic and iron-mediated protein. ${ }^{16}$ Our study revealed that improvement of anti-oxidant component and reduction of oxidative stress markers could protect from renal damage via anti-oxidant mediated mechanism. Recent literature focused that oxidative stress, inflammation and fibrosis may be produced by angiotensin-II mediated pathway. ${ }^{39}$ One of our very recent studies found that angiotensin-converting enzyme inhibitor successfully normalized $\mathrm{CCl}_{4}$ induced hepatic damage, oxidative stress and fibrosis. ${ }^{40}$ Depending on that result we also propose that bitter melon might have the activity to suppress renin-angiotensin-system and thereby could regulate oxidative stress as well as down-regulate cytokines production. However, further study would be necessary to explore the exact molecular mechanism of $M$. charantia on renal protection.

\section{AUTHOR'S CONTRIBUTIONS}

Md. Ashraful Alam conceived the idea, designed the study and monitored all protocols for the study. Md Abu Taher Sagor and Nabila Tabassum carried out the animal study and performed the biochemical assay. Md Abu Taher Sagor and Md. Moshfequr Rahman carried out statistical analysis. Hasan Mahmud Reza and Md. Ashraful Alam evaluated the histology and wrote the manuscript. All the authors have checked and approved the manuscript.

\section{CONFLICT OF INTEREST}

The authors declare no conflict of interest about this manuscript.

\section{REFERENCES}

1. Salant, D. 2016. Podocyte Expression of B7-1/CD80: Is it a reliable biomarker for the treatment of proteinuric kidney diseases with abatacept? J. Am. Soc.Nephrol. 27, 963-965.

2. Inzucchi, S.E., Bergenstal, R.M., Buse, J.B., Diamant, M., Ferrannini, E., Nauck, M., Peters, A.L., Tapas, A., Wender, R. and Matthews, D.R. 2015. Management of hyperglycemia in type 2 diabetes, 2015: A patient-centered approach: update to a position statement of the American Diabetes Association and the European Association for the Study of Diabetes. Diabetes Care. 38, 140-149.

3. Vardapetyan, H., Tiratsuyan, S. and Hovhannisyan, A., editors. Hepatoprotective activity of leaf extract of Laurus nobilis $\mathrm{L}$. against $\mathrm{CCl}_{4}$ induced hepatotoxicity in rats. 3rd International Conference on Nanotechnologies and Biomedical Engineering; 2016: Springer. 
4. Jia, R., Du, J.-L., Cao, L.-P., Liu, Y.-J., Xu, P. and Yin, G.J. 2016. Protective action of the phyllanthin against carbon tetrachloride-induced hepatocyte damage in Cyprinus carpio. In Vitro Cell. Dev. Biol. Anim. 52, 1-9.

5. Agbafor, K.N., Ezeali, C., Akubugwo, E., Obiudu, I., Uraku, A., Ogbanshi, M., Edwin, N. and Ugwu, O. 2015. Cardioprotective effect of leaf and root extracts of Newbouldia laevis against carbon tetrachloride inducedcardiotoxicity in albino rats. Eur. J. Med. Plants. 9.

6. Ismail, A.F., Moawed, F.S. and Mohamed, M.A. 2015. Protective mechanism of grape seed oil on carbon tetrachloride-induced brain damage in $\gamma$-irradiated rats. $J$. Photochem. Photobiol. B: Biol. 153, 317-323.

7. Aslan, A., Boydak, D., Can, MI. and Kuloglu, T. 2015. Nigella sativa improves the carbon tetrachloride-induced lung damage in rats through repression of Erk/Akt pathway. Bangladesh J. Pharmacol. 10, 654-659.

8. Kim, K.-T., Lee, D., Seo, Y.K. and Kim, S.Y. 2015. The effects of $\mathrm{CCl}_{4}$ on the expressions of aquaporin and superoxide dismutase in the kidney of the spontaneously hypertensive rat. Korean J. Phy. Anthropol. 28, 87-101.

9. Hismiogullari, A.A., Hismiogullari, S.E., Karaca, O., Sunay, F.B., Paksoy, S., Can, M., Kus, I., Seyrek, K. and Yavuz, O. 2015. The protective effect of curcumin administration on carbon tetrachloride $\left(\mathrm{CCl}_{4}\right)$-induced nephrotoxicity in rats. Pharmacol. Reports. 67, 410-416.

10. Suzek, H., Celik, I., Dogan, A. and Yildirim, S. 2015. Protective effect and antioxidant role of sweetgum (Liquidambar orientalis) oil against carbon tetrachlorideinduced hepatotoxicity and oxidative stress in rats. Pharm. Biol. 54, 451-457.

11. Masuda, H., Hironaka, S., Matsui, Y., Hirooka, S., Hirai, M., Hirata, Y., Akao, M. and Kumagai, H. 2015. Comparative study of the antioxidative activity of culinary herbs and spices, and hepatoprotective effects of three selected lamiaceae plants on carbon tetrachloride-induced oxidative stress in rats. Food Sci. Technol. Res. 21, 407-418.

12. Hassan, M.H., Bahashawan, S.A., Abdelghany, T.M., AbdAllah, G.M. and Ghobara, M.M. 2015. Crocin abrogates carbon tetrachloride-induced renal toxicity in rats via modulation of metabolizing enzymes and diminution of oxidative stress, apoptosis, and inflammatory cytokines. $J$. Biochem. Mol. Toxicol. 29, 330-339.

13. Reza, H.M., Sagor, M.A.T. and Alam, M.A. 2015. Iron deposition causes oxidative stress, inflammation and fibrosis in carbon tetrachloride-induced liver dysfunction in rats. Bangladesh J. Pharmacol. 10, 152-159.

14. Liu, Y.-J., Du, J.-L., Cao, L.-P., Jia, R., Shen, Y.-J., Zhao, C.-Y., Xu, P. and Yin, G.-J. 2015. Anti-inflammatory and hepatoprotective effects of Ganoderma lucidum polysaccharides on carbon tetrachloride-induced hepatocyte damage in common carp (Cyprinus carpio L.). Int. Immunopharmacol. 25, 112-120.

15. Liu, R., Ruan, T., Song, S., Lin, Y. and Jiang, G. 2015. Determination of synthetic phenolic antioxidants and relative metabolites in sewage treatment plant and recipient river by high-performance liquid chromatography-electrospray tandem mass spectrometry. J. Chromatography A. 1381, 1321.

16. Alam, M.A., Uddin, R., Subhan, N., Rahman, M.M., Jain, P. and Reza, H.M. 2015. Beneficial role of bitter melon supplementation in obesity and related complications in metabolic syndrome. J. of Lipids. 2015.

17. Sagor, A.T., Chowdhury, M.R., Tabassum, N., Hossain, H., Rahman, M. and Alam, A. 2015. Supplementation of fresh ucche (Momordica charantia L. var. Muricata Willd) prevented oxidative stress, fibrosis and hepatic damage in $\mathrm{CCl}_{4}$ treated rats. BMC Complement. Altern. Med. 15, 115.

18. Niehaus, W. and Samuelsson, B. 1968. Formation of malonaldehyde from phospholipid arachidonate during microsomal lipid peroxidation. Eur. J. Biochem. 6, 126-130.

19. Tracey, W.R., Tse, J. and Carter, G. 1995. Lipopolysaccharide-induced changes in plasma nitrite and nitrate concentrations in rats and mice: pharmacological evaluation of nitric oxide synthase inhibitors. J. Pharmacol. Exp. Ther. 272, 1011-1015.

20. Witko-Sarsat, V., Friedlander, M., Capeillère-Blandin, C., Nguyen-Khoa, T., Nguyen, A. T., Zingraff, J., Jungers, P. and Descamps-Latscha, B. 1996. Advanced oxidation protein products as a novel marker of oxidative stress in uremia. Kidney Int. 49, 1304-1313.

21. Tiwari, B.K., Kumar, D., Abidi, A.B. and Rizvi, S.I. 2014. Efficacy of composite extract from leaves and fruits of medicinal plants used in traditional diabetic therapy against oxidative stress in alloxan-induced diabetic rats. ISRN Pharmacol. 7.

22. Chance, B. and Maehly, A. 1954. Assay of catalases and peroxidases. Methods Biochem. Anal. 1, 357-424.

23. Khan, R.A. 2012. Protective effects of Sonchus asper (L.) Hill, (Asteraceae) against $\mathrm{CCl}_{4}$ induced oxidative stress in the thyroid tissue of rats. BMC Complement Altern Med.12, 181.

24. Jollow, D.J., Mitchell, J.R., Zampaglione, N. and Gillette, J.R. 1974. Bromobenzene-induced liver necrosis. protective role of glutathione and evidence for 3,4-Bromobenzene oxide as the hepatotoxic metabolite. Pharmacol. 11, 151-169.

25. Ma, L., Liu, J., Li, N., Wang, J., Duan, Y., Yan, J., Liu, H., Wang, H. and Hong, F. 2010. Oxidative stress in the brain of mice caused by translocated nanoparticulate $\mathrm{TiO} 2$ delivered to the abdominal cavity. Biomaterials. 31, 99-105.

26. Kielstein, H., Suntharalingam, M., Perthel, R., Song, R., Schneider, S. M., Martens-Lobenhoffer, J., Jäger, K., BodeBöger, S.M. and Kielstein, J.T. 2015. Role of the endogenous nitric oxide inhibitor ADMA and BDNF in depression and behavioural changes: clinical and preclinical data in chronic kidney disease. Nephrol. Dial. Transplant. 30, 1699-705.

27. Yan, D., Tu, Y., Jiang, F., Wang, J., Zhang, R., Sun, X., Wang, T., Wang, S., Bao, Y. and Hu, C. 2015. Uric acid is independently associated with diabetic kidney disease: a cross-sectional study in a Chinese population. PloS One. 10, e0129797. 
28. Sautin, Y.Y. and Johnson, R.J. 2008. Uric acid: the oxidantantioxidant paradox. Nucleosides, Nucleotides and Nucleic Acids 27, 608-619.

29. Sim, J.J., Rutkowski, M.P., Selevan, D.C., Batech, M., Timmins, R., Slezak, J.M., Jacobsen, S.J. and Kanter, M.H. 2015. Kaiser Permanente creatinine safety program: A mechanism to ensure widespread detection and care for chronic kidney disease. Am. J. Med. 128, 1204-1211. e1201.

30. Alam, M.A., Chowdhury, M.R.H., Jain, P., Sagor, M.A.T. and Reza, H.M. 2015. DPP-4 inhibitor sitagliptin prevents inflammation and oxidative stress of heart and kidney in two kidney and one clip (2K1C) rats. Diabetol. Metab. Syndr. 7, $1-10$.

31. Yilmaz-Ozden, T., Can, A., Karatug, A., Pala-Kara, Z., Okyar, A. and Bolkent, S. 2014. Carbon tetrachlorideinduced kidney damage and protective effect of Amaranthus lividus L. in rats. Toxicol. Ind. Health. 32, 1143-1152.

32. Morakinyo, A., Oludare, A.A. and Adegoke, O. 2012. Protective effects of alpha lipoic acid on carbon tetrachloride-induced liver and kidney damage in rats. Brit. J. Pharmacol. Toxicol. 3, 21-28.

33. Quan, J., Piao, L., Wang, X., Li, T. and Yin, X. 2009. Rossicaside B protects against carbon tetrachloride $\square$ induced hepatotoxicity in mice. Basic Clin. Pharmacol. Toxicol. 105, 380-386.

34. Haines, D., Lekli, I., Teissier, P., Bak, I. and Tosaki, A. 2012. Role of haeme oxygenase $\square 1$ in resolution of oxidative stress $\square$ related pathologies: focus on cardiovascular, lung, neurological and kidney disorders. Acta Physiologica. 204, 487-501.

35. Zhou, L.L., Cao, W., Xie, C., Tian, J., Zhou, Z., Zhou, Q., Zhu, P., Li, A., Liu, Y. and Miyata, T. 2012. The receptor of advanced glycation end products plays a central role in advanced oxidation protein products-induced podocyte apoptosis. Kidney Int. 82, 759-770.
36. Khan, R.A., Khan, M.R and Sahreen, S. 2012. CCl $\mathrm{Cl}_{4}$-induced hepatotoxicity: protective effect of rutin on p53, CYP2E1 and the antioxidative status in rat. BMC Complement. Altern. Med. 12, 178

37. Watanabe, H., Miyamoto, Y., Honda, D., Tanaka, H., Wu, Q., Endo, M., Noguchi, T., Kadowaki, D., Ishima, Y. and Kotani, S. 2013. p-Cresyl sulfate causes renal tubular cell damage by inducing oxidative stress by activation of NADPH oxidase. Kidney Int. 83, 582-592.

38. Ganie, S.A., Haq, E., Hamid, A., Qurishi, Y., Mahmood, Z., Zargar, B.A., Masood, A. and Zargar, M.A. 2011. Carbon tetrachloride induced kidney and lung tissue damages and antioxidant activities of the aqueous rhizome extract of Podophyllum hexandrum. BMC Complement. Altern Med. 11, 17.

39. Zhong, J., Guo, D., Chen, C.B., Wang, W., Schuster, M., Loibner, H., Penninger, J.M., Scholey, J.W., Kassiri, Z. and Oudit, G.Y. 2011. Prevention of angiotensin II-mediated renal oxidative stress, inflammation, and fibrosis by angiotensin-converting enzyme 2. Hypertension. 57, 314322.

40. Reza, H.M., Tabassum, N., Sagor, M.A., Chowdhury, M.R., Rahman, M., Jain, P. and Alam, M.A. 2016. Angiotensinconverting enzyme inhibitor prevents oxidative stress, inflammation, and fibrosis in carbon tetrachloride-treated rat liver. Toxicol. Mech. Methods. 26, 46-53. 